\title{
Twenty-First Century Skills in Finance: Prospects for a Profound Job Transformation
}

\author{
Alina Lavrinenko \\ Leading Expert at the Department for Human Capital Research, alavrinenko@hse.ru
}

Natalia Shmatko

Head, Department for Human Capital Research, nshmatko@hse.ru

Institute for Statistical Studies and Economics of Knowledge, National Research University Higher School of Economics, 11 Miasnitskaya St., 101000 Moscow

\begin{abstract}
$\mathrm{T}$

his paper analyzes the impact disruptive technologies, such as artificial intelligence (AI), big data, the internet of things, and blockchain, upon conventional banking professions and skill sets. Our conclusions are based upon a large array of data collected over the course of a survey of highly qualified personnel conducted in 2017-2018 using text mining, case studies, and expert interviews. The changing requirements for workers and to their competences were assessed taking into account the level of technological development (including the use of relevant products and services by Russian and international companies) as well as the probability of

certain professional skills being substituted by automated solutions in the medium term. The results indicate that impact of technologies upon various functional segments of banks' operations is varied. While most of the analyzed professions are evolving towards broader functionality, others are sliding into the "obsolete" group. In the next few years, automated systems will take full responsibility for data collection and its initial analysis, though they will not replace bank personnel fully given that they simply remain tools that help boost workers' productivity and efficiency, extend the information base, accelerate decision-making, cut costs, and reduce risks.
\end{abstract}

Keywords: 21 st century skills; job automation; banking professions; breakthrough technologies; competences for the future
Citation: Lavrinenko A., Shmatko N. (2019) Twenty-First Century Skills in Finance: Perspectives of Profound Jobs Transformation. Foresight and STI Governance, vol. 13, no 2, pp. 42-51. DOI: 10.17323/2500-2597.2019.2.42.51 
I $\mathrm{n}$ recent years many financial organizations have turned into advanced "laboratories", testing grounds for cutting-edge technologies more conservative (or less flexible) organizations hesitate to apply. Many banks have already started to optimize their personnel responsible for handling paperwork and performing routine cognitive tasks, such as tellers, cashiers, controllers, call center operators, client and credit managers, analysts, and consultants. If ten years ago a major problem of the banking sector was optimizing bank branches, now abandoning this format altogether is on the agenda. Financial organizations are trying to morph into autonomous high-tech ecosystems with the smallest possible number of staff.

The application of digital technologies is causing major changes in skill requirements: the demand for new professions is on the rise, while many of the existing jobs are becoming obsolete. The very meaning of the concept of "profession" is changing: the set of competences a worker trained for in a specific profession is expected to cease being definite and static; competency profiles are changing in line with technological and organizational changes, turning into "dynamic portfolios". Accordingly, quantitative measures are no longer sufficient for predicting companies' personnel requirements, while the role of qualitative techniques is increasing. Companies and their HR departments need to adopt the flexible career paths model, taking into account that workers may be transferred between the company's various units due to the full or partial automation of their jobs. The pace of change has been accelerating: the tasks workers have to accomplish are becoming increasingly complex, while predicting skill and competency requirements is steadily turning into an ever greater challenge.

The lack of clear and adequate communications between employers and the education system results in the oversupply of workers with irrelevant competences, combined with a growing shortage of highly sought-after knowledge and skills.

The paper presents the results of a study focused on assessing the consequences (actual and expected) of applying disruptive technologies developed in key digital economy segments (such as artificial intelligence (AI), big data, the internet of things, blockchain) in conventional banking professions related to the support of basic banking operations (the so-called back office). The analysis of changing requirements for workers and their competences took into account companies' current level of technological development (the application of various products and services, including pilot ones as well as the current demand for specific skills and competences), and the probability of various responsibilities being substituted by automated solutions in the next several years. It was concluded that professions may evolve at the same companies at different rates and technologies' impact upon various segments of banks' operations was sufficiently varied, which made managing human capital a much more challenging task.

\section{Literature Review}

Accelerated science and technology progress, along with growing uncertainty, dictate the need to constantly improve approaches to analyzing skills requirements to quickly meet the changing needs of the economy. The proliferation of AI technologies and products such as deep machine learning, natural language processing, computer vision, biometric authentication, smart agents, and personal assistants prompted the emergence of numerous studies analyzing the role of technological breakthroughs in changing the professional structure of the workforce. Among other things it was also caused by the rate of technological change: the time between the emergence of a technology and its mass proliferation is getting much shorter. Futurists discuss the probable arrival of a technological singularity - a hypothetical point in time when S\&T progress becomes so fast and complex humans will be no longer able to comprehend it [Sandberg, 2010].

Analyzing the substitution of human labor by machines due to the application of robotics or AI technologies, in particular arrival of so-called "technological unemployment" has a special place in labor economics studies [Kim et al., 2017]. The main theoretical aspects of this phenomenon were addressed by classical economists already (see [Vivarelli, 2007] for more). One of the more radical forecasts concerned the evolution of professions represented in the US economy [Frey, Osborne, 2017]. According to the authors' estimates, technologies will develop so rapidly that in ten years' time up to $50 \%$ of workers will be pushed out of the labor market. The widening of the gap between highly- and lowly-skilled workers is predicted. Frey and Osborne's methodology was also applied in a number of other country-specific studies. For example, an analysis of computer technologies' impact on the Japanese labor market indicated a $55 \%$ probability of automation [David, 2017], while in the OECD countries the relevant figures varied: in Korea the share of potentially automated jobs was $6 \%$, and in Austria this figure was as high as $12 \%$ [Arntz et al., 2016]. These differences may reflect not just the level of investments in technological development, but also different levels of education, and different job structures in various countries. A number of studies in this area were criticized for not taking into account the diverse nature of occupation-specific responsibilities and tasks (they can be routine or creative, requiring the ability to deal with non-standard situations). Also, if technolo- 
gies' impact on the labor market is analyzed not in broad terms such as professions or occupations, but on the level of specific jobs, it turns out that only $18.2 \%$ of workers may be facing the threat of automation. The reason is that an average worker, regardless of their profession, performs numerous tasks that cannot be algorithmized, such as planning, problem solving, presentation, etc. [Arntz et al., 2017].

Also worthy of note are the studies by McKinsey and Boston Consulting Group (BCG) based on the US $\mathrm{O}^{*} \mathrm{NET}$ professions database data: according to them, at least $30 \%$ of professional responsibilities can be automated at the current level of technological development, while the number of working hours for employees whose professions will not disappear by 2027 due to the application of AI in the banking sector would drop by $29 \%$ [McKinsey Global Institute, 2017; BCG, 2018].

Despite the abundance of approaches, and the extensive critique [Ahmad, Blaug, 1973, Colclough, 1990, Psacharopoulos, 1991], almost all attempts to predict national-level demand for skills are based on the so-called "manpower requirements approach" (MRA) [Hopkins, 2002]. In a number of variations it was applied in developed and developing countries alike, for example, in the US, the UK, Germany, the Netherlands, Italy, the Czech Republic, and France [Wong et al, 2004]. The MRA is a top-down approach: it is based on the assumption that increased output in an industry will lead to proportional growth of demand for all kinds of skills the industry requires [Williems, 1998]. The MRA's basic premise, and a major aspect of its criticisms is that workers do not change their activities. According to the basic methodology, "supply of workers specializing in other professions, even with similar skill sets" is unimportant for estimating possible supply/demand imbalances in a particular profession [El Achkar, 2010]. At the same time, many researchers stress that such forecasts are based on the erroneous belief that the amount of labor in the economy is set, while it has been empirically proved that increased productivity leads to economic agents' increased income, which in turn results in increased consumer and investment demand - which cannot be met without involving additional labor [Krugman, 2003; Sala, 2011; Walker, 2007]. Also, the approach under consideration does not pay sufficient attention to assessing technology's impact upon the nature and content of work in the scope of specific professions.

Empirical studies in labor economics suggest that the current technological development leads not so much to the elimination as to the modernization of jobs [Kapeliushnikov, 2017]. Technological potential is frequently overestimated, while infrastructural, economic, regulatory, and ethic barriers hindering the dissemination of technologies are ig- nored. At the current stage, technology allows one to accomplish only a limited set of objectives, such as image, voice, and other biometric data recognition; assessing the probability of bankruptcy; analyzing data collected by various devices; predicting hardware faults, and so on. (weak artificial intelligence). Existing systems are not self-aware and do not have the ability to change themselves (strong artificial intelligence) [Bringsjord, Govindarajulu, 2018]. The problem of "interpretable artificial intelligence" has not been solved either. Automated systems cannot give feedback and explain the logic of making particular decisions to users, which is critical in areas such as healthcare, national security, and international law [Brynjolfsson, Mitchell, 2017; Gunning, 2017].

Thus, keeping in mind the limitations, in the near future technological development will probably contribute to carrying out specific job responsibilities more efficiently, rather than fully substituting workers. A shift from routine physical and cognitive operations (which in all probability will be carried out by machines and algorithms) to nonroutine ones is expected [OECD, 2017].

The digitalization of the financial services industry, along with the growth of the mobile banking segment and the fintech revolution are turning into important drivers for changing skill and competency requirements in the financial sector. The digitalization of key processes at banks allows one to cut costs and improve client experience. A growing number of banks' clients are willing to be served remotely. This is prompted by increased mobile internet usage, more convenient mobile application interfaces, the proliferation of contactless payments, and the growing number of banking products available online. Leading financial organizations are trying to turn into "high-tech companies with a banking license" by implementing their digital transformation strategies. A PricewaterhouseCoopers (PwC) survey showed that in 2017 consumers were quite comfortable with the "digital multichannel" model, i.e., they did not prefer any single channel for interacting with their banks (an internet browser or a mobile application). A similar survey conducted in 2018 indicated that a significant proportion of clients were switching to exclusively mobile banking $[P w C, 2018]$. Therefore, it becomes increasingly relevant not only to optimize bank branches' personnel, but also organize back office operations as efficiently as possible.

\section{Methodology}

Over the course of this study we used various quantitative and qualitative techniques including text mining, case studies, and expert interviews. To analyze the current state of the subject area and identify major skill and competency demand 
trends, the semantic analysis of academic papers and publications in industry-specific media on the future of the labor market was conducted, along with vacancies published on Russian and international websites such as job vacancy aggregators using the iFORA Intelligent Data Analytics System designed by the HSE Institute for Statistical Studies and Economics of Knowledge [Bakhtin et al., 2017; Gokhberg et al., 2017]. Additionally, a collection of more than a hundred case studies was assembled from open sources, reflecting the practices of applying technological solutions in selected areas by banking and other organizations. The case studies were analyzed in terms of full or partial substitution of "classic" banking professions.

To obtain and generalize expert opinions, 60 in-depth interviews were conducted with representatives of the relevant professions and HR departments at the top five Russian financial organizations - experts in selected technology domains and corporate education. An expert interview guide was used, comprising 22 questions about the digital transformation of financial companies, the application of advanced technological solutions, staff training and retraining, future prospects for the banking sector's job market (including potential for automating the work), professions that were becoming obsolete, and new skill and competency requirements.

A situation was modeled in the course of the study when banking organizations applied all breakthrough technological solutions available in the middle of 2018 in areas such as AI, big data, the internet of things, and blockchain. Organizations' previous experience in applying digital products and services was taken into account when analyzing changing requirements for workers and their competences, along with the probability of certain professional responsibilities being substituted by automated solutions in the next few years. This should prompt companies' skill requirements to match their new objectives and the need to either cut personnel, hire new professionals, or retrain the existing workers.

Thirty back office professions were selected for the purposes of the study: positions that did not involve serving the financial organization's clients or partners directly. The choice was due to back office processes' suitability for being substituted by algorithmized solutions given their supportive functionality in relation to front office ones, and the relatively uncomplicated (in cognitive terms) nature of many relevant professions (such as supporting and processing business deals, administration, calculations, managerial accounting, bookkeeping, etc.) [Anagnoste, 2017]. Between three and five main responsibilities (functions) were identified for each profession. Open-source data was used for this purpose such as vacancies advertised on ma- jor Russian job aggregator websites (such as hh.ru, career.ru, finexecutive.com). Having compared the currently available technological solutions with the nature of back office workers' common responsibilities, conclusions were made regarding the potential for their automation, demand for new skills, and need to extend the range of competences.

\section{Results}

About 18,000 job vacancy descriptions published by top 15 Russian financial sector organizations in September-December 2018 found in the aforementioned open sources were processed in the course of the iFORA analysis using natural language processing and machine learning techniques. The text mining process comprised five main stages: primary natural language processing, syntacticsemantic analysis, subject modeling, structuring (clustering), and the identification of semantic patterns. All meaningful terms were automatically extracted from the texts, and then vector representations of the terms and documents were built by assessing similarity (proximity) of their meanings. Subsequent statistical analysis and data clustering allowed for projecting a multidimensional model of the required competencies landscape into a twodimensional semantic map illustrating the current demand for competences and skills (Figure 1).

This map shows that even now employers in the financial sector are largely interested in jobseekers' digital skills, such as knowledge of programming languages and specific features of using them in the banking sector; experience with banking software; search optimization skills, etc. Sales skills are still in demand, including in the B2B segment, along with the so-called soft skills - workers' personal characteristics unrelated to specific subject areas, which affect their working style (communication, stress resistance, persistence, etc.). Legal, securities handling, and clerical skills were included in specific clusters.

A detailed analysis of leading international and Russian banking and IT companies' practical experience in applying breakthrough technological solutions in areas such as AI, big data, the internet of things, and blockchain (among them were BBVA, JP Morgan Chase, Goldman Sachs, Credit Suisse, Wells Fargo, Amazon, Apple, Facebook, Google, etc.) allowed to build a comprehensive picture of the current state of technological development, and of technologies' application. On the basis of expert interviews and estimates made over the course of the case studies a "combined effect matrix" was built, demonstrating how and to what extent the main bank back office professions' responsibilities were going to change. It was shown that when banks apply digital technologies, carrying out a significant share of the currently relevant responsibilities would require an extended set of 


\section{Figure 1. Mapping Competency Requirements in the Financial Sector}

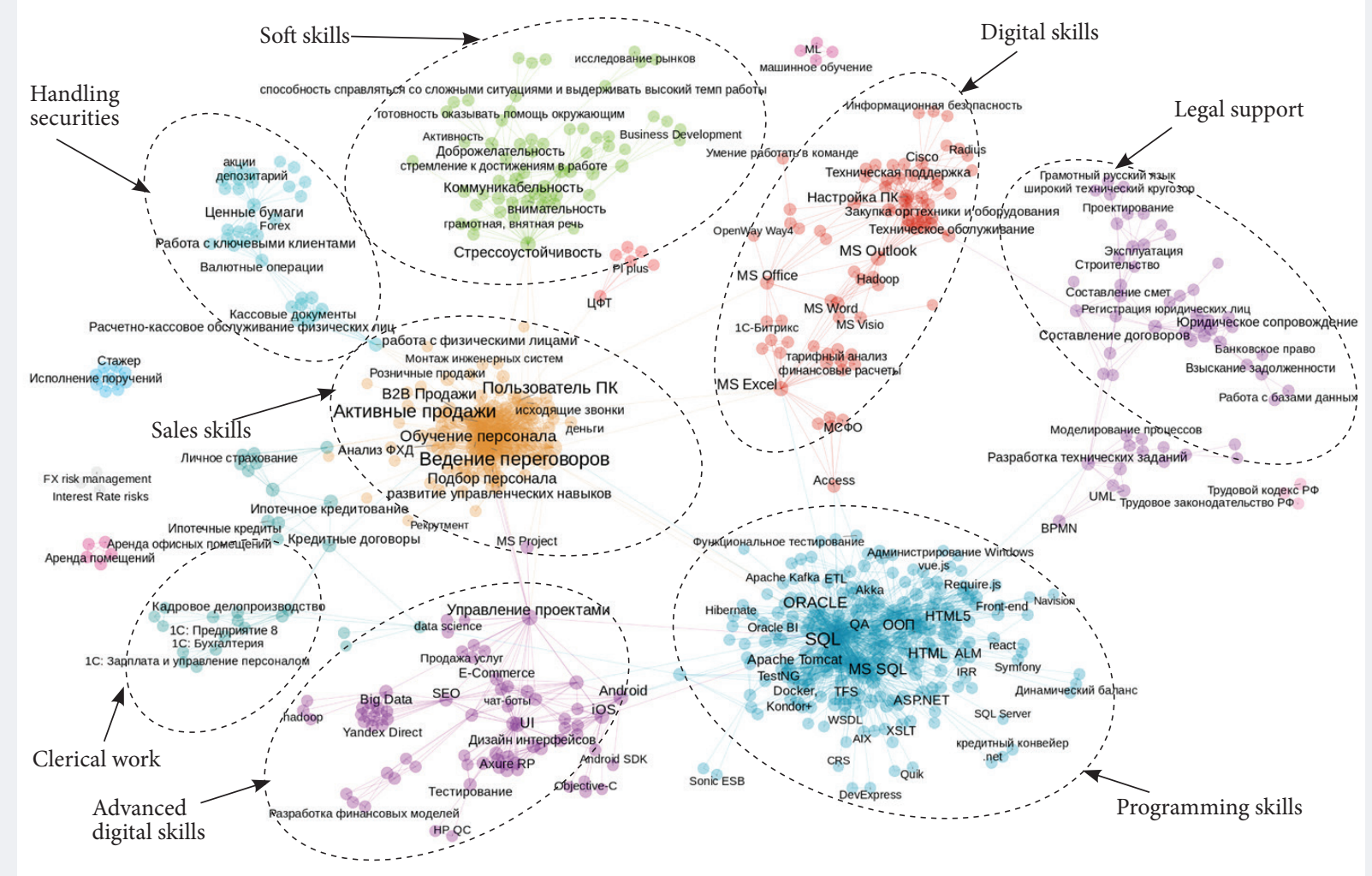

Note. The scan was conducted with particular using of the Russian language wording of the keywords. Baseline data is obtained from the HeadHunter jobs service (hh.ru).

Source: HSE ISSEK Smart Big Data Analytics System iFORA.

competences. Some responsibilities were facing the threat of automation, while others were not going to change significantly. The key trend was not the complete substitution or elimination of certain back office professions, but their uneven transformation, to a different extent and at different rates. A predictive estimate of combined effects of AI, big data, the internet of things, and blockchain technologies on selected banking professions is presented in Table 1.

Strategy analysts' and business analysts' responsibilities are the least susceptible to the impact of technologies and poorly suited for substitution since they are high-level activities that require systemic thinking. AI-based products would allow one to partially automate responsibilities related to implementing business strategies and optimizing business processes, but humans will remain responsible for drafting development plans.

The development of automated systems and voicebased biometrics will contribute to the substitution of call centers' staff responsible for handling routine (standard) enquiries. Potentially these workers will move on to dealing with non-standard (conflict) issues and serving premium clients (e.g. as "concierges").

Due to the steady improvement of models' accuracy and the reduced decision-making time (occasionally to just a few seconds), the conventional responsibilities of risk analysts will be losing relevance. However, the changing of the existing and the emergence of new risks would require constant improvements of the assessment systems and approaches to minimizing their probability. Such workers will be mostly concerned with developing methodologies, since even testing and validating risk models, along with stress testing, would be gradually automated and become machines' responsibility - thus freeing time for human workers to develop more effective risk management tools.

The automation of routine banking processes (processing legal documents, finding debtors, and their assets, etc.) already contributes to freeing a significant amount of distressed asset specialists' work time, which can be spent on more complex tasks such as negotiating with borrowers, cessionaries, procurers of non-liquid collateral, and so on. However, these responsibilities will also be substi- 


\section{Table. 1. Estimated Combined Effect of Prospective Technologies on Responsibilities of Banks' Back Office Personnel}

\begin{tabular}{|c|c|c|c|}
\hline Profession & $\begin{array}{l}\text { Responsibilities likely to be replaced by } \\
\text { technological solutions }\end{array}$ & $\begin{array}{l}\text { Responsibilities requiring extended } \\
\text { competency set }\end{array}$ & $\begin{array}{l}\text { Responsibilities } \\
\text { not likely to } \\
\text { significantly } \\
\text { change }\end{array}$ \\
\hline $\begin{array}{l}\text { New product } \\
\text { analysts }\end{array}$ & Analysing product sales & $\begin{array}{l}\text { Building financial models } \\
\text { Designing business models }\end{array}$ & \\
\hline Strategy analysts & Analysing financial accounts & $\begin{array}{l}\text { Monitoring strategy implementation } \\
\text { Analysing top-level business processes }\end{array}$ & $\begin{array}{l}\text { Developing com- } \\
\text { pany strategy } \\
\text { Agreeing strategies } \\
\end{array}$ \\
\hline Underwriters & $\begin{array}{l}\text { Collecting information on clients' creditwor- } \\
\text { thiness } \\
\text { Analysing collected data }\end{array}$ & Preparing conclusions & \\
\hline Auditors & $\begin{array}{l}\text { Auditing business processes } \\
\text { Preparing audit schedules } \\
\text { Monitoring steps taken to remedy violations }\end{array}$ & $\begin{array}{l}\text { Monitoring external audits } \\
\text { Designing corrective actions following audits }\end{array}$ & \\
\hline Business analysts & $\begin{array}{l}\text { Describing business processes } \\
\text { Monitoring implementation of proposals }\end{array}$ & $\begin{array}{l}\text { Assessing economic effect of business processes' } \\
\text { improvement }\end{array}$ & $\begin{array}{l}\text { Optimising business } \\
\text { processes }\end{array}$ \\
\hline Brand managers & & $\begin{array}{l}\text { Designing sets of advertising and marketing ac- } \\
\text { tions to improve brand trust and loyalty } \\
\text { Forecasting, marketing plans' effectiveness, and } \\
\text { managing their implementation } \\
\text { Designing brand promotion strategies }\end{array}$ & \\
\hline Accountants & $\begin{array}{l}\text { Handling paperwork } \\
\text { Accounting and bookkeeping } \\
\text { Revising documents }\end{array}$ & Dealing with public authorities & \\
\hline Designers & & $\begin{array}{l}\text { Designing marketing project concepts, presen- } \\
\text { tation materials' layouts, logos, etc. } \\
\text { Taking part in web design } \\
\text { Designing, and creating layouts of marketing } \\
\text { materials }\end{array}$ & \\
\hline $\begin{array}{l}\text { Compliance } \\
\text { managers }\end{array}$ & $\begin{array}{l}\text { Identifying, assessing, and monitoring com- } \\
\text { pliance risks }\end{array}$ & $\begin{array}{l}\text { Monitoring and auditing company employees' } \\
\text { compliance with policies and procedures } \\
\text { Taking steps to prevent and minimise conflict } \\
\text { of interest risks } \\
\text { Implementing anticorruption measures }\end{array}$ & \\
\hline Credit analysts & $\begin{array}{l}\text { Comprehensively analysing potential bor- } \\
\text { rowers' creditworthiness } \\
\text { Establishing possible lending conditions and } \\
\text { deal structures }\end{array}$ & $\begin{array}{l}\text { Drawing up credit reports } \\
\text { Structuring loans } \\
\text { Communicating with product divisions }\end{array}$ & \\
\hline $\begin{array}{l}\text { Marketing ana- } \\
\text { lysts }\end{array}$ & $\begin{array}{l}\text { Collecting data about users' behaviour } \\
\text { Assessing marketing strategies }\end{array}$ & $\begin{array}{l}\text { Supporting analytical data marts } \\
\text { Designing prototype data marts for accounting } \\
\text { purposes }\end{array}$ & \\
\hline $\begin{array}{l}\text { Integrated com- } \\
\text { munications } \\
\text { managers }\end{array}$ & $\begin{array}{l}\text { Analysing results, preparing progress and } \\
\text { final reports about integrated campaigns }\end{array}$ & $\begin{array}{l}\text { Developing integrated media plans, conducting } \\
\text { and optimising advertising campaigns } \\
\text { Developing integrated media strategies to pro- } \\
\text { mote products and services } \\
\text { Preparing recommendations to increase ef- } \\
\text { ficiency }\end{array}$ & \\
\hline $\begin{array}{l}\text { Product manag- } \\
\text { ers }\end{array}$ & & $\begin{array}{l}\text { Forecasting strategies' effectiveness } \\
\text { Preparing user stories and user interaction sce- } \\
\text { narios }\end{array}$ & $\begin{array}{l}\text { Managing product } \\
\text { launches } \\
\text { Developing product } \\
\text { strategies }\end{array}$ \\
\hline Tax controllers & $\begin{array}{l}\text { Checking tax incentives' applicability, and } \\
\text { correctness of tax calculation } \\
\text { Preparing audit result reports }\end{array}$ & $\begin{array}{l}\text { Taking part in tax planning } \\
\text { Conducting internal tax audits }\end{array}$ & \\
\hline $\begin{array}{l}\text { Call centre op- } \\
\text { erators }\end{array}$ & $\begin{array}{l}\text { Routing calls depending on the nature of } \\
\text { enquiry }\end{array}$ & $\begin{array}{l}\text { Taking steps to address customer requests } \\
\text { Taking customer calls } \\
\text { Providing information to customers }\end{array}$ & \\
\hline $\begin{array}{l}\text { Portfolio man- } \\
\text { agers }\end{array}$ & & $\begin{array}{l}\text { Taking part in methodology development, clas- } \\
\text { sification of tools, assessment and assignment of } \\
\text { risk metrics } \\
\text { Assessing management results, preparing pro- } \\
\text { posals to improve them in risk/return terms } \\
\text { Proposing investment ideas, managing portfo- } \\
\text { lios } \\
\text { Designing and implementing investment strate- } \\
\text { gies taking into account risks associated with } \\
\text { client profiling, and their specific wishes }\end{array}$ & \\
\hline
\end{tabular}


Table 1 continued

\begin{tabular}{|c|c|c|c|}
\hline Profession & $\begin{array}{l}\text { Responsibilities likely to be replaced by } \\
\text { technological solutions }\end{array}$ & $\begin{array}{l}\text { Responsibilities requiring extended } \\
\text { competency set }\end{array}$ & $\begin{array}{c}\text { Responsibilities } \\
\text { not likely to } \\
\text { significantly } \\
\text { change }\end{array}$ \\
\hline Risk analysts & $\begin{array}{l}\text { Verifying deals and incidents in line with } \\
\text { risk assessment procedures } \\
\text { Collecting client data } \\
\text { Analysing competitive environment }\end{array}$ & $\begin{array}{l}\text { Building risk models } \\
\text { Preparing summary findings and reports on } \\
\text { evaluation and analysis results }\end{array}$ & \\
\hline $\begin{array}{l}\text { Venture com- } \\
\text { munications spe- } \\
\text { cialists }\end{array}$ & & $\begin{array}{l}\text { Maintaining corporate information publications } \\
\text { Building and developing a corporate communi- } \\
\text { cation network }\end{array}$ & $\begin{array}{l}\text { Covering corporate } \\
\text { events }\end{array}$ \\
\hline $\begin{array}{l}\text { Collateral spe- } \\
\text { cialists }\end{array}$ & $\begin{array}{l}\text { Monitoring current collateral portfolio } \\
\text { Preliminary assessment of collateral } \\
\text { Creating and maintaining collateral files }\end{array}$ & $\begin{array}{l}\text { Preparing summary findings on collateral as- } \\
\text { sessments }\end{array}$ & \\
\hline $\begin{array}{l}\text { Treasury special- } \\
\text { ists }\end{array}$ & $\begin{array}{l}\text { Opening accounts } \\
\text { Investing, and attracting cash, securities, and } \\
\text { other instruments } \\
\text { Processing transaction passports } \\
\text { Monitoring and executing operational cash } \\
\text { flow }\end{array}$ & & \\
\hline $\begin{array}{l}\text { Macroeconomic } \\
\text { research special- } \\
\text { ists }\end{array}$ & Providing consulting services & $\begin{array}{l}\text { Conducting macroeconomic research, prepar- } \\
\text { ing forecasts } \\
\text { Financial and economic modelling }\end{array}$ & \\
\hline $\begin{array}{l}\text { Client operations } \\
\text { monitoring spe- } \\
\text { cialists }\end{array}$ & $\begin{array}{l}\text { Collecting and analysing client data } \\
\text { Monitoring transactions subject to manda- } \\
\text { tory control, and unusual transactions }\end{array}$ & Assessing clients' risks & \\
\hline $\begin{array}{l}\text { Distressed asset } \\
\text { specialists }\end{array}$ & $\begin{array}{l}\text { Managing and analysing problem asset port- } \\
\text { folios } \\
\text { Assessing cost-effectiveness of overdue debt } \\
\text { collection } \\
\text { Monitoring compliance with established col- } \\
\text { lection standards and targets }\end{array}$ & $\begin{array}{l}\text { Reviewing and analysing debtors' financial situ- } \\
\text { ation (individual and corporate ones) } \\
\text { Developing models for handling problem debts }\end{array}$ & \\
\hline $\begin{array}{l}\text { Financial institu- } \\
\text { tions specialists }\end{array}$ & $\begin{array}{l}\text { Exchanging business and financial informa- } \\
\text { tion with partners } \\
\text { Concluding and maintaining agreements } \\
\text { with financial organisations }\end{array}$ & $\begin{array}{l}\text { Analysing organisations' financial situation } \\
\text { Agreeing terms of service, opening correspon- } \\
\text { dent accounts }\end{array}$ & \\
\hline $\begin{array}{l}\text { Liquidity man- } \\
\text { agers }\end{array}$ & & $\begin{array}{l}\text { Managing liquidity } \\
\text { Optimising liquidity models } \\
\text { Preparing short- and long-term cash flow fore- } \\
\text { casts }\end{array}$ & \\
\hline $\begin{array}{l}\text { Financial man- } \\
\text { agement special- } \\
\text { ists }\end{array}$ & & $\begin{array}{l}\text { Preparing budget plans for company units } \\
\text { Budget control and execution } \\
\text { Collecting, processing, and analysing data on } \\
\text { units' activities }\end{array}$ & \\
\hline $\begin{array}{l}\text { Business plan- } \\
\text { ning managers }\end{array}$ & Analysing data, preparing reports & $\begin{array}{l}\text { Preparing management reports } \\
\text { Preparing business plans for the next year; cal- } \\
\text { culating financial models for strategic areas } \\
\text { Preparing medium- and long-term forecasts } \\
\text { and plans }\end{array}$ & \\
\hline Economists & $\begin{array}{l}\text { Assessing potential partners to estimate co- } \\
\text { operation prospects }\end{array}$ & $\begin{array}{l}\text { Analysing prospects for providing new kinds of } \\
\text { services } \\
\text { Calculating costs and payback periods of opera- } \\
\text { tions and services }\end{array}$ & \\
\hline Legal counsels & Contract work & $\begin{array}{l}\text { Providing legal support for company operations } \\
\text { Providing legal consulting services } \\
\text { Ensuring internal regulatory documents' com- } \\
\text { pliance with legal requirements }\end{array}$ & \\
\hline HR managers & Recruitment & $\begin{array}{l}\text { Organising adaptation events } \\
\text { Preparing training plans } \\
\text { Evaluating workers' performance }\end{array}$ & $\begin{array}{l}\text { Dealing with non- } \\
\text { standard issues }\end{array}$ \\
\hline
\end{tabular}


tuted by machines. In addition to having general and financial legal knowledge, distressed asset specialists would need to be able to easily handle not only existing databases but also emerging and potential sources of "useful" data and extract, process, and analyze new information including the mastery of big data mining techniques.

The gradual automation of internal auditors' "manual" responsibilities (such as preparing audit schedules and proposing corrective action based on audit results for routine operations) will significantly simplify and make their work easier. However, non-standard situations would still require human attention. Also, auditors' responsibilities are established by regulatory authorities and relevant guidance for dealing with specific issues, which would slow down their transformation.

Computerized data processing using cloud technologies, which relieves workers from huge amounts of hard "mechanical" work, leads to reduced demand for such economists' and accountants' responsibilities as collecting and structuring open-source data for subsequent analysis of the market and economic situations, borrowers' financial and economic activities, and other routine tasks such as conducting standardized calculations, preparing routine reports, control of tax payments and currency operations, monitoring business deals with one's own shares and bonds, and managing shortterm liquidity.

In marketing, as in other areas where analytics plays an important role, responsibilities such as collecting information about user behavior, marketing strategy evaluation, and even drafting initial approaches to optimizing client communication channels seem to be best-suited for automation. This would completely relieve marketing analysts and integrated communications managers from manual analytics, but they will have to acquire basic skills to adjust relevant technologies to meet specific marketing needs and efficiently interpret solutions suggested by automated systems.

Technologies applied in the field of law and legislation will allow one to automate such responsibilities as drafting documents, finding necessary information, drawing up model contracts, and advising on common issues. These functions will be transferred to chat bots and law robots. However, they will not be able to handle non-standard issues. The development of blockchain technologies and the introduction of "smart contracts" into daily practice will require changing the competency portfolio. Professionals who not only have legal knowledge but can also work with blockchain software code will be required.

Compliance managers' responsibilities will change in similar ways. Technology will relieve these workers of routine operations and human contribution will be required only in non-standard situations as well as preparing summary opinions about compliance risks.

\section{Conclusions}

The results of the study give grounds to predict a significant, qualitative transformation of the skill sets the financial sector's workers will need to have following the application of breakthrough technologies. Semantic analysis of academic publications and the industry media, case studies reflecting best practices for applying such technologies, and information collected over the course of expert interviews at leading Russian financial sector organizations lead to the following conclusions:

Artificial intelligence is a priority for banking operations' digital transformation the world over [Accenture, 2018; Bain\&Company, 2017; Financial Brand, 2018; Financial Times, 2018]; it radically changes the collection and analysis of information about clients, investment targets, funding sources, and so on. At many banks such technologies help reduce the time required to serve clients, plan call centers' workload, identify questionable transactions, for credit scoring, analysis, predictive modeling of early deposit withdrawal risks, algorithmic trading, and so on. Advanced models have the ability of perception, which allows them to produce impressive results on the pilot project level or when performing routine operations. However, the lack of cognitive abilities makes the full substitution of human intelligence with machines impossible.

Big data analytics is turning into a key competence, defining banks' future competitiveness, making the mass personalization of services possible and accomplishing most of banks' objectives (such as predicting client behavior, optimizing product lines, assessing default risks, etc.).

The internet of things can be applied in all areas where there is a need for remote monitoring of various objects' state and to collect data for predictive analytics, such as production facilities (smart production), retail, healthcare, urban planning and logistics (smart cities, smart transport, smart parking lots), and construction (smart homes). The internet of things allows banks to move to a new level of understanding their clients' needs through collecting and analyzing additional data about their behavior and preferences.

The adoption of blockchain systems in the banking sector, trade financing, logistics, by public authorities and in other areas will eliminate the need to verify, duplicate, and backup data. This, in turn, might lead to the disappearance or transformation of "intermediary" professions related to data checking and verification, such as auditors, notaries, factoring and credit history specialists, and others. So far blockchain remains at the experi- 
mental stage with a number of issues (first of all regulatory ones) remaining unresolved. However, numerous financial sector companies, retailers, and transport and logistics operators are actively testing projects based on distributed registry technologies, thus creating and promoting demand for blockchain specialists.

Workers performing all kinds of banking responsibilities will have to work in a high-tech environment and deal with high-level tasks. This primarily implies developing relevant methodologies, modeling, and decision-making based on advanced analytics.
In the future workers will need to constantly extend and "reconfigure" their skill set (competency portfolio) to match the newly emerging responsibilities. Therefore, various soft skills are becoming particularly important, which allow professionals to adapt to changing markets and technologies.

This paper is based on results of the research conducted in the framework of the HSE Basic Research Program and supported by a subsidy provided by the Russian Academic Excellence Project '5-100'. The authors would like to thank P. Bakhtin, E. Vaniushina, and E.Miazina for their valuable contribution to preparing and conducting this study.

\section{References}

Accenture (2018) Realizing the full value of AI in banking. Available at: https://www.accenture.com/gb-en/insights/banking/futureworkforce-banking-survey, accessed: 14.06.2018.

Ahmad B., Blaug M. (eds.) (1973) The Practice of Manpower Forecasting: A Collection of Case Studies, Amsterdam: Elsevier.

Anagnoste S. (2017) Robotic automation process - The next major revolution in terms of back office operations improvement. Proceedings of the International Conference on Business Excellence, vol. 11, no 1, pp. 676-686.

Arntz M., Gregory T., Zierahn U. (2016) The Risk of Automation for Jobs in OECD Countries: A Comparative Analysis (OECD Social, Employment and Migration Working Paper 189), Paris: OECD.

Arntz M., Gregory T., Zierahn U. (2017) Revisiting the risk of automation. Economics Letters, vol. 159, pp. 157-160.

Bain\&Company (2017) Evolving the Customer Experience in Banking. Available at: http://www.bain.com/publications/articles/evolvingthe-customer-experience-in-banking.aspx, accessed 14.11.2018.

Bakhtin P.D., Saritas O., Chulok A., Kuzminov I., Timofeev A. (2017) Trend Monitoring for Linking Science and Strategy. Scientometrics, vol. 111, no 3, pp. 2059-2075.

BCG (2018) The Impact of Artificial Intelligence (AI) on the Financial Job Market, Boston, MA: Boston Consulting Group. Available at: http://image-src.bcg.com/Images/BCG-CDRF-The-Impact-of-AI-on-the-Financial-Job-Market_Mar\%202018_ENG_tcm9-187843. pdf, accessed 28.09.2018.

Bringsjord S., Govindarajulu N.S. (2018) Artificial Intelligence. The Stanford Encyclopedia of Philosophy (Fall 2018 Edition) (ed. E.N. Zalta). Available at: https://plato.stanford.edu/archives/fall2018/entries/artificial-intelligence/, accessed: 11.02.2019.

Brynjolfsson E., Mitchell T. (2017) What can machine learning do? Workforce implications. Science, no 358(6370), pp. 1530-1534.

Colclough C. (1990) How can the manpower planning debate be resolved? Quantitative Techniques in Employment Planning (eds. R. Amjad, C. Colclough, N. Garcia, M. Hopkins, R. Infante, G. Rogers), Geneva: International Labour Office, pp. 1-23.

David B. (2017) Computer technology and probable job destructions in Japan: An evaluation. Journal of the Japanese and International Economies, vol. 43, pp. 77-87.

El Achkar S. (2010) A Companion Guide to Analyzing and Projecting Occupational Trends (CSLS Research Report 2010-07), Ottawa: Centre for the Study of Living Standards.

Financial Brand (2018) Artificial Intelligence and The Banking Industry's \$1 Trillion Opportunity. Available at: https://thefinancialbrand. com/72653/artificial-intelligence-trends-banking-industry/, accessed 14.11.2018.

Financial Times (2018) AI in banking: The reality behind the hype. Available at: https://www.ft.com/content/b497a134-2d21-11e8-a34a7e7563b0b0f4, accessed 24.11.2018.

Frey C.B., Osborne M.A. (2017) The future of employment: How susceptible are jobs to computerisation? Technological Forecasting and Social Change, vol. 114, pp. 254-280. Available at: https://www.sciencedirect.com/science/article/pii/S0040162516302244, accessed 04.06.2018.

Gokhberg L., Kuzminov I., Bakhtin P., Tochilina E., Chulok A., Timofeev A., Lavrynenko A. (2017) Big-Data-Augmented Approach to Emerging Technologies Identification: Case of Agriculture and Food Sector (HSE Working Paper WP BRP 76/STI/2017), Moscow: HSE.

Gunning D. (2017) Explainable artificial intelligence (xai), Arlington, VA: Defense Advanced Research Projects Agency (DARPA). Available at: https://www.cc.gatech.edu/ alanwags/DLAI2016/(Gunning)\%20IJCAI-16\%20DLAI\%20WS.pdf, accessed 15.02.2019.

Hopkins M.(2002)Labourmarketplanningrevisited,New York:PalgraveMacMillan. Availableat:http://dx.doi.org/10.1057/9781403920263, accessed 15.02.2019.

Kapelyushnikov R.I. (2017) Tekhnologicheskii progress — pozhiratel' rabochikh mest? [Is technological change a devourer of jobs?]. Voprosy Ekonomiki, no 11, pp. 111-140 (in Russian).

Kim Y.J., Kim K., Lee S. (2017) The rise of technological unemployment and its implications on the future macroeconomic landscape. Futures, vol. 87, pp. 1-9.

Krugman P. (2003) Lumps of labor. The New York Times, 10.03.2003. Available at: https://www.nytimes.com/2003/10/07/opinion/lumpsof-labor.html, accessed 15.02.2019.

McKinsey Global Institute (2017) A future that works: Automation, employment and productivity, New York: McKinsey Global Institute Available at: https://www.mckinsey.com/ /media/mckinsey/featured\%20insights/Digital\%20Disruption/Harnessing\%20 automation\%20for\%20a\%20future\%20that\%20works/MGI-A-future-that-works-Executive-summary.ashx, accessed 04.06.2018. 
OECD (2017) OECD Employment Outlook 2017, Paris: OECD. Available at: http://dx.doi.org/10.1787/empl_outlook-2017-en, accessed 04.06.2018.

Psacharopoulos G. (1991) From manpower planning to labour market analysis. International Labour Review, vol. 130, no 4, pp. 459-474.

PwC (2018) PwC's 2018 Digital Banking Consumer Survey: Mobile users set the agenda, London: PricewaterhouseCoopers. Available at: https://www.pwc.com/us/en/financial-services/publications/assets/pwc-fsi-whitepaper-digital-banking-consumer-survey.pdf, accessed 14.06.2018.

Sala G. (2011) Approaches to skills mismatch in the labour market: A literature review. Papers: Revista de Sociologia, vol. 96, no 4, pp. 1025-1045.

Sandberg A. (2010) An overview of models of technological singularity. Paper presented at the Roadmaps to AGI and the Future of AGI Workshop, Lugano, Switzerland, March. Available at: http://agi-conf.org/2010/wp-content/uploads/2009/06/agi10singmodels2.pdf, accessed 15.06.2018.

Vivarelli M. (2007) Innovation and Employment: A Survey (IZA Discussion Paper 2621), Bonn: IZA.

Walker T. (2007) Why economists dislike a lump of labor. Review of Social Economy, vol. 65, no 3, pp. 279-291.

WEF (2016) The Future of Jobs Employment, Skills and Workforce Strategy for the Fourth Industrial Revolution, Geneva: World Economic Forum. Available at: http://www3.weforum.org/docs/WEF_FOJ_Executive_Summary_Jobs.pdf, accessed: 15.06.2018).

Williems E. (1998) Interpreting Gaps in Manpower Forecasting Models. Labour, vol. 12, no 4, pp. 633-641. Available at: http://dx.doi. org/10.1111/1467-9914.00083, accessed 15.06.2018.

Wong J.M.W., Chan A.P.C., Chiang Y.H. (2004) A critical review of forecasting models to predict manpower demand. Australasian Journal of Construction Economics and Building, vol. 4, no 2, pp. 43-56.

World Bank (2006) Skill Development in India: The Vocational Education and Training System, Washington, D.C.: World Bank. 